\title{
Immunomodulation of autoimmune responses with monoclonal antibodies and immunoadhesins: treatment of ocular inflammatory disease in the next millennium
}

\author{
Andrew D Dick, John D Isaacs
}

Non-infective inflammatory disease is a significant cause of ocular and associated systemic morbidity and, in cases of posterior intraocular conditions, results in severe visual loss in over $30 \%$ of cases. ${ }^{12}$ Steroids have long been used for the treatment of conditions such as uveitis, ${ }^{34}$ although their therapeutic window is small. ${ }^{5}$ In addition to the successful use of cyclosporin A over the past two decades, newer immunomodulatory agents have also been introduced such as tacrolimus ${ }^{6}$ and mycophenolate mofetil. ${ }^{78}$ Despite their efficacy, all of these treatments have major drawbacks-patients require long term therapy and systemic side effects are common. Additionally, a significant proportion of patients remain refractory to therapy. With improvement in our knowledge of the immunobiology of non-infectious ocular inflammatory disease, however, ${ }^{910}$ and in our ability to develop and produce recombinant proteins, it has become possible to specifically target cells and mediators of the immune system. Novel therapeutics arising from such work include specific monoclonal antibodies (mAbs) and receptor-Ig fusion proteins (immunoadhesins or IAs). ${ }^{11}$

\section{Understanding the immunobiology of non-infectious ocular inflammatory disease identifies specific targets for therapy}

Non-infectious posterior intraocular inflammation (PSII), which includes uveitic disorders, and ocular surface inflammatory disorders, including scleritis and peripheral ulcerative keratitis (PUK), are arguably the commonest cause of immune mediated visual loss. Fifty per cent of these "autoimmune" disorders are limited to the eye (organ specific), whereas the remainder form part of more generalised diseases, including connective tissue and multisystem granulomatous disorders. Understanding basic immunopathological mechanisms from patients is hindered by the rarity of some diseases, genetic and clinical heterogeneity of patients, and limited access to clinical material from the site of disease. Consequently, most significant advances have arisen from experimental models of autoimmune disease, particularly with reference to the eye. ${ }^{12}$ Models of both posterior and anterior uveitis demonstrate a pivotal role for antigen specific CD4+ (T helper 1 (Th1)) $\mathrm{T}$ cells, ${ }^{13}{ }^{14}$ and proinflammatory soluble cytokines including interferon $\gamma$, interleukin 2 (IL-2), tumour necrosis factor $\alpha(\mathrm{TNF}-\alpha)$, and IL-12. A current view is that activation of autoaggressive antigen specific $\mathrm{T}$ cells occurs systemically, and that activated cells then "home" to the eye where they are presented with antigen by local antigen presenting cells (APC). The systemic factors which activate these cells are unknown, but their local interactions perpetuate Th1 cytokine secretion, chemotaxis of non-specific inflammatory cells, and stimulate chemokine, TNF- $\alpha$, and interferon gamma (IFN- $\gamma$ ) secretion by, for example, activated retinal pigment epithelium (RPE). ${ }^{15}$ This results ultimately in immune targeted tissue damage.

Concerning intraocular inflammation and corneal allografts, the eye is considered an immunoprivileged site with active immunoregulatory mechanisms, ${ }^{16}$ yet both PSII and rejection are relatively common. With respect to PSII there are APC within choroid ${ }^{17}$ and, putatively, within retina, ${ }^{18}$ and $T$ cells can adhere to both the RPE and retinal vascular endothelium via ICAM- $1 .{ }^{16}$ Furthermore, in conditions such as sympathetic ophthalmia, retinal vascular endothelium expresses ICAM-1, VCAM-1, and ELAM- $1^{19}$ implicating leucocyte adhesion to vascular endothelium in the inflammatory response; and in vivo cell tracking indicates that activated $\mathrm{T}$ cells adhere to retinal and choroidal endothelium. ${ }^{20}$ There is now also increasing evidence for antigen specific Th1-T cell activation in PSII in humans. Thus, patients with uveitis have circulating $\mathrm{T}$ cells $\mathrm{s}^{21-25}$ specific for putative retinal antigens such as $\mathrm{S}$ antigen (S-Ag) and interphotoreceptor retinoid binding protein (IRBP), which are potent experimental immunogens. ${ }^{26}$ In addition, studies show that immune responses in uveitic patients are proinflammatory, corresponding to the Th1 CD $4+\mathrm{T}$ cell responses seen in animal models. Increased CD4+ $\mathrm{T}$ cell IL-2r and IFN- $\gamma$ expression, ${ }^{27} 28$ and circulating soluble IL-2 $\mathrm{r}^{30}$ and ICAM-1 $1^{31-33}$ have all been observed in uveitis.

Despite their clinical differences, as described above the immunopathogenesis of ocular surface and orbital inflammatory conditions appears similar to that of PSII, in particular presumed T cell APC interactions and Th1 T cell effector mechanisms and cytokine production. Consistent with this observation, successful preclinical trials of immunotherapeutic agents including cyclosporin $\mathrm{A},{ }^{34}$ tacrolimus, ${ }^{6}$ and mycophenolate mofetil, ${ }^{35}{ }^{36}$ have led to their clinical use today in the full range of ocular inflammatory conditions. Subtle differences in immunopathogenesis may become apparent as therapies become more refined, however, and ultimately result in customised approaches to treatment. Indeed, mAbs and IAs which specifically target $\mathrm{T}$ cells and cytokines are now being applied to experimental models of ocular inflammatory disease (Table 1) and, in addition to confirming potential targets for therapeutic immunomodulation, these have also contributed to our understanding of the diseases themselves. Such studies have shown that abrogation or suppression of ocular inflammatory disease including corneal transplant rejection and scleritis can be achieved by neutralising IL- $2,{ }^{37}{ }^{38} \mathrm{IL}-12,{ }^{46}$ and TNF- $\alpha .{ }^{40}{ }^{41}$ Additionally, targeting of CD $4^{1442} 43$ and adhesion molecules ${ }^{44} 45$ can also be beneficial. The precise therapeutic mechanisms are not always clear, however, and caution is necessary before 
Table 1 mAb therapy targeting cell surface antigens, cytokines, and adhesion molecules and recombinant cytokine therapy in models of immune mediated ocular inflammation and corneal allograft rejection

\begin{tabular}{|c|c|c|c|}
\hline & & References & \\
\hline & Target & Suppression ${ }^{\star}$ & $\begin{array}{l}\text { No effect/ } \\
\text { exacerbationt }\end{array}$ \\
\hline Cell surface & $\begin{array}{l}\text { CD } 4 \\
\text { MHC class II } \\
\text { CD8 }\end{array}$ & $\begin{array}{l}14,42,43,49,50 \\
51\end{array}$ & 52 \\
\hline Adhesion targets & $\begin{array}{l}\text { ICAM-1/LFA-1 } \\
\text { VLA-4 }\end{array}$ & $\begin{array}{l}45,53-57 \\
56,57\end{array}$ & \\
\hline Anti-cytokine $\mathrm{mAb}$ & $\begin{array}{l}\text { IL-12 } \\
\text { TNF- } \alpha\end{array}$ & $\begin{array}{l}46 \\
47\end{array}$ & $58-60$ \\
\hline $\begin{array}{l}\text { RHU cytokine } \\
\text { therapy }\end{array}$ & $\begin{array}{l}\text { IL-12 } \\
\text { IL-4 } \\
\text { TNF- } \alpha\end{array}$ & $\begin{array}{l}39 \\
40,41\end{array}$ & 61 \\
\hline
\end{tabular}

*These studies have shown that treatment with such mAb or recombinant cytokine suppresses target organ destruction.

†These studies have shown no effect or provide evidence of paradoxical effects of therapy in some forms of experimental ocular inflammatory models although generally not experimental models of PSII.

extrapolation to the clinic. For example, although IL-12 neutralisation suppressed disease, ${ }^{46}$ IL-12 itself did the same in susceptible strains. ${ }^{39}$ Similarly, neutralising TNF activity can suppress disease either during $\mathrm{T}$ cell priming or during effector responses ${ }^{40}{ }^{41} 47$ but can also exacerbate autoimmune disease. The latter effect was evident in genetically manipulated mice, possibly because chronic TNF exposure attenuates $\mathrm{T}$ cell responses (TCR) and thereby downregulates $\mathrm{T}$ cell activation. ${ }^{48}$ Regardless of the precise mechanism, however, the specific targeting of effector cells or molecules with mAbs or IAs can provide powerful therapeutic effects.

\section{Reprogramming the immune system}

In animal models of autoimmune disease and transplantation, it is now possible to use brief courses of mAbs directed at $\mathrm{T}$ cells, to turn off autoaggressive responses permanently. Initially, mAbs which depleted CD4 and/or CD8 cells, were employed to induce tolerance to foreign skin grafts. ${ }^{11}$ The rationale was that these would eradicate any lymphocytes capable of rejecting the foreign skin, and newly generated lymphocytes would become tolerant to the transplant which was grafted during the period of lymphopenia. It was subsequently demonstrated that even more powerful effects could be obtained using nondepleting mAbs. Under these circumstances, it seemed that lymphocytes which contacted foreign antigen while coated with $\mathrm{mAb}$ were tolerised rather than activated. Several $\mathrm{T}$ cell specificities were effective, but CD4 and CD8 blockade seemed indispensable when there was a large antigenic disparity between donor and recipient. In general, the greater the disparity the more aggressive was the therapy required. Under appropriate cireumstances, however, it was possible to induce tolerance across a complete MHC mismatch. Furthermore, it was possible to induce tolerance in mice that were already rejecting their grafts, a situation akin to established autoimmunity. It was puzzling that tolerance was maintained even years after $\mathrm{mAb}$ therapy had ceased (in general, treatment was for a few weeks only) as new T cells would be emerging from the thymus which could theoretically attack and destroy the graft. A major discovery, however, was that following $\mathrm{mAb}$ therapy, tolerant lymphocytes could pass on their tolerant phenotype to other potentially autoreactive cells. This process was termed infectious tolerance and a related process, termed linked suppression, suggested that lymphocyte regulation also involved the APC. ${ }^{62}$ Thus, non-depleting $\mathrm{T}$ cell mAbs can induce tolerance to autoantigens, and regulatory interactions are then set in place to maintain the tolerant state, although exact mechanisms remain as yet undefined.

Similar work has taken place in animal models of autoimmune disease, such as experimental allergic encephalomyelitis (EAE), collagen induced arthritis, diabetes, and systemic lupus erythematosus (SLE). ${ }^{63-66}$ In general, treatment has targeted all $\mathrm{T}$ cells via their surface CD4 and/or CD8 antigens, although in a few diseases it has been possible to target just the known pathogenic clones. EAE is the classic example, whereby anti-TCR mAbs can be used specifically to target the cells causing damage. ${ }^{67}$ This is the exception rather than the rule, however, and in the outbred human population it seems unlikely that such focusing of treatment will be possible in any particular disease.

Our knowledge of $\mathrm{T}$ cell activation is expanding and so too are the potential targets for immunomodulation. The most exciting prospects at present are the targeting of $\mathrm{T}$ cell co-stimulatory molecules such as CD28 and CD40 ligands. Both of these molecules must be ligated for a $\mathrm{T}$ cell to become fully activated and, in vitro, blocking either during cognate antigen recognition results in $\mathrm{T}$ cell anergy. In this state $\mathrm{T}$ cells are effectively switched off and do not become activated when they re-encounter antigen. This observation has been exploited in the treatment of animal models of autoimmune disease, where mAbs against the B7.1 molecule (a ligand of CD28) prevents diabetes development in the NOD mouse, and CTLA4-Ig, an IA that also targets CD28, blocks the development of EAE. ${ }^{68} 69$

While cytokines have also been targeted, in general such treatments are only likely to provide short term relief of inflammatory or allergic symptoms, rather than long term disease modulation. The exception will be if it proves possible to deviate an immune response from Th 1 dominance to Th2 dominance. As hinted at above, a bias towards Th1 immune responses is evident in diseases such as rheumatoid arthritis, multiple sclerosis, diabetes, and inflammatory eye disease. In contrast, Th2 $\mathrm{T}$ cells (which secrete IL-4, IL-5, and IL-10), lead predominantly to humoral immune responses. It is possible that blocking Th1 cytokines and/or administering Th2 cytokines may result in a permanent and favourable deviation of the immune response in Th1 type diseases. Evidence supporting this possibility has derived from the administration of TNFr$\mathrm{Ig}$, an anti-TNF $\alpha \mathrm{IA}$, to rats with EAU. ${ }^{41}$

\section{Immunomodulation and human autoimmune diseases}

$\mathrm{T}$ cell $\mathrm{mAbs}$ have been used widely to provide transient immunosuppression in patients rejecting allografts, but their use in autoimmunity is in its infancy. Furthermore, when such treatments have been tried, the results have often been disappointing. Rheumatoid arthritis is one of the commonest autoimmune diseases, and most experience has been gained in this condition. Recently, CD4 therapy has been shown to provide transient symptomatic relief in rheumatoid arthritis, but few patients achieve long term benefit. There are a number of pitfalls in transferring the technology from animals to humans, however. ${ }^{70}{ }^{71}$ The major barrier is a lack of understanding of how anti-T cell therapies work. Although we can demonstrate phenomena such as infectious tolerance, we do not know how our therapies achieve this. In particular, we have no molecular surrogates to guide therapy. Under these circumstances, lack of efficacy is as likely to represent insufficient dosing as an ineffective therapy (the doses administered to patients are, on a weight for weight basis, orders of magnitude less than those required to induce tolerance in small mammals). Additionally, the ethics of new therapies means that the patients selected often have rheumatoid arthritis in its 
later stages, when $\mathrm{T}$ cells may be less important, and much of the damage has already been done. In contrast with the situation in rheumatoid arthritis, dramatic responses and long term remissions have been obtained in ocular inflammatory diseases, ${ }^{72}$ systemic vasculitis, and multiple sclerosis. ${ }^{74}{ }^{75}$ It is unclear why these diseases should make better therapeutic targets than rheumatoid arthritis, although in vasculitis the therapeutic agent may simply have better access to the site of disease. The treatment that has proved effective in these conditions, Campath- $1 \mathrm{H}$, is a lymphocytotoxic $\mathrm{mAb}$ that binds to all $\mathrm{T}$ and $\mathrm{B}$ cells. Therapy is followed by a long term $\mathrm{T}$ lymphocytopenia, and, although this does not appear to cause increased infections, the treatment is currently reserved for severe and refractory disease.

In contrast with anti- $\mathrm{T}$ cell therapies, cytokine blockade provides potent anti-inflammatory effects in rheumatoid arthritis, ${ }^{76} 77$ and an IA targeting $\mathrm{TNF} \alpha$ is now licensed in the USA. A mAb, which is already licensed for the treatment of Crohn's disease, is also likely to be licensed for rheumatoid arthritis soon. These treatments have proved highly effective at minimising the symptoms of the disease, but long term administration does appear necessary to maintain the beneficial effects. A recombinant form of the IL-1 receptor antagonist is also in late stage trials in rheumatoid arthritis, and has a promising therapeutic profile. ${ }^{78}$

\section{Designing novel immunomodulators for autoimmune diseases}

The design of novel immunomodulators is a blossoming area. The first $\mathrm{mAbs}$ were produced from murine lymphocytes, which had a number of disadvantages. ${ }^{79}$ Immunogenicity was significant, and limited the number of times that a specific $\mathrm{mAb}$ could be given to a patient. Additionally, the murine $\mathrm{C}$ region did not interact optimally with the human $\mathrm{Fc} \gamma$ receptors and complement. The organisation of Ig genes made it a simple matter to create chimeric mAbs using recombinant DNA technology. ${ }^{80}$ These retained the murine $\mathrm{V}$ region, but the murine $\mathrm{C}$ region was replaced with a human equivalent. Consequently, the immunogenicity was reduced, and the interaction with human effector mechanisms was restored. The anti-TNF $\alpha \mathrm{mAb}$ licensed for rheumatoid arthritis is chimeric. Humanisation further reduced the immunogenicity of mAbs by replacing most of the murine v-region "framework" with equivalent human sequence, leaving only the critical complementarity determining regions (CDRs, which dictate binding specificity), as foreign. ${ }^{81}$ These can still evoke an immune response, but less frequently than the original murine $\mathrm{mAb}$. It is now possible to create synthetic mAbs in the test tube, from viruses encoding human Ig genes, and transgenic mice also exist which produce fully human mAbs when immunised. In theory, even the CDRs are human when mAbs are produced using either of these technologies. ${ }^{82}$

Immunoadhesins are also readily made using recombinant DNA techniques. Fully human mAbs and immunoadhesins may still require modification, however. Thus, depending on the $\mathrm{C}$ region (isoptype), a mAb may effectively deplete target cells. If this not a desired characteristic, it is now relatively simple to mutate critical effector "motifs" within the $\mathrm{C}$ region to disable effector mechanisms. Thus, most novel immunomodulators that now enter clinical trials are truly "designer" mAbs or IAs. ${ }^{83}$

\section{Risk/benefits of $\mathrm{mAb}$ and IA therapy}

The potential benefits of biological therapies are great, but these must be viewed in the context of potential risks. In fact, although follow up is relatively short, the therapeutic ratio of these agents seems favourable. For anti-T cell agents, the major concern is the likelihood of side effects secondary to immunosuppression. Although there have been occasional reports of opportunistic infections following such treatments ${ }^{84}$ a recent analysis of patients who received the lymphocyte depleting mAb Campath- $1 \mathrm{H}$ for rheumatoid arthritis did not suggest an increased risk of opportunistic infection or death during the first 5 years of follow up, despite quite profound and sustained lymphopenia. Furthermore, the trend now is to use non-depleting agents, which are not only safer but also more potent, because of their ability to facilitate the re-establishment of immune regulation (see above). Additionally, because courses of anti- $\mathrm{T}$ cell biological therapies are relatively short in duration, risks should be less than those associated with long term conventional immunosuppression. Infections have also been reported in association with anti-TNF $\alpha$ therapies which, at least in rheumatoid arthritis, require long term administration for a sustained therapeutic effect. TNF $\alpha$ is important in the immune response against intracellular pathogens, and it is possible that susceptibility to such infections will be increased in patients receiving continuous $\mathrm{TNF} \alpha$ blockade. This cytokine is also important in the control of certain malignancies, but more extended follow up is required before any conclusions can be drawn regarding tumour risks associated with its chronic blockade. There have also been reports of the development of secondary autoimmune diseases, particularly SLE and anti-phospholipid syndrome, associated with anti-TNF- $\alpha$ therapy. It is not clear why such diseases should develop, but in all cases, serology and symptoms (if any) have reversed upon cessation of treatment. Although mAbs may evoke an immune response in recipients these are rarely problematic, although anaphylactoid reactions have been reported in occasional patients. The most likely outcome of an immune response is decreased efficacy, as witnessed with low doses of the chimeric anti-TNF $\alpha$ $\mathrm{mAb} .^{85}$ Interestingly, immunogenicity was negligible if the $\mathrm{mAb}$ was co-administered with a low dose of methotrexate, a well established therapy for rheumatoid arthritis. The anti-TNF- $\alpha$ IA, which does not contain foreign protein sequence, does not appear to be immunogenic. Despite this, its half life is much shorter than that of the mAb, requiring twice weekly subcutaneous administration, compared with an intravenous infusion every 8 weeks for the $\mathrm{mAb}$. In contrast with these agents, the IL-1 receptor antagonist has to be administered daily by subcutaneous injection. Although these dosing regimens may seem inconvenient, compliance depends largely on efficacy in a disease such as rheumatoid arthritis, and there have been few problems reported in trials to date.

The only other significantly reported adverse effect of biological therapies is the first dose reaction, which accompanies the initial infusion of several reagents, particularly those directed at cell membranes. ${ }^{78}$ The pathogenesis of the reactions, which varies from mild fever to chest tightness and hypotension, varies between agents. Ultimately, however, the symptoms appear to relate to the release of cytokines from either target cells or crosslinked effector cells. If necessary, the syndrome can be prevented by predosing with corticosteroids, and a severe reaction can be controlled with symptomatic measures and temporary cessation of the infusion. Because the syndrome appears to depend on the $\mathrm{Fc} \gamma$ receptor crosslinking by the therapeutic $\mathrm{mAb}$, its incidence is likely to decrease as designer mAbs are developed, which do not bind those receptors. 


\section{mAb and immunoadhesin therapy in ocular inflammatory disease}

In patients with sight threatening ocular inflammatory disease there is an unquestionable need to immunosuppress to preserve vision, ${ }^{12}$ and treat accompanying immune mediated systemic disease. The risk-benefit ratio of immunosuppression in perceived "well" eye patients often restrains its use in sufficiently potent regimens in general ophthalmological practice. The need to commence adequate immunosuppression is exemplified in scleritis, however, where sight threatening ocular disease may be followed by life threatening systemic disease in conditions such as Wegener's granulomatosis. ${ }^{86}$ In conditions restricted to the eye, the ideal therapy would be one which both suppressed disease and reconstituted homeostatic immunoregulation, preferably using only a short course of therapy. ${ }^{87}$ While the use of mAbs has thus far been appropriately restricted to patients refractory to conventional immunosuppressive therapy, the results suggest that they may fulfil these requirements. Thus, case reports have documented the success of anti-CD4 mAbs and Campath-1H (see above) in the treatment of refractory autoimmune endogenous posterior uveitis. ${ }^{72} 88$ Futhermore, a single report has documented corneal graft acceptance using Campath-1H in a patient with a history of recurrent graft rejection refractory to conventional immunosuppression. ${ }^{73}$ In these reports, not only was disease suppression possible using mAbs, but baseline immunosuppression could also be reduced while maintaining remission. Since these early reports, additional patients have received specific mAb therapy. In a cohort of patients with a spectrum of refractory ocular inflammatory diseases, Campath-1H therapy stabilised inflammation and enabled reduction in baseline immunosuppression to minimal levels (Dick et al, submitted). The above results are encouraging and wider application is warranted at this stage, although close observation remains essential. Additionally, Whitcup recently referred to an ongoing trial at the NEI, Bethesda, ${ }^{89}$ using humanised anti-Tac (CD25, IL-2r) $\mathrm{mAb}$ in a pilot phase I/II trial for non-infectious posterior uveitis. Despite necessary long term administration of anti-Tac $\mathrm{mAb}$ for suppression of renal allograft rejection, ${ }^{90}$ the provisional results are encouraging and their full report is thus eagerly awaited.

\section{Prospects}

A major goal for the future must be to gain a better understanding of how these therapies achieve their therapeutic effects. The successful use of anti-T cell mAbs in animal models was the culmination of iterative experiments in which promising therapies were slowly modified until they provided the desired end point of long term immunomodulation. No surrogate markers were defined to guide treatment, however. Therefore, when therapy is unsuccessful in patients, it may simply be that the dose or dosing regimen is inappropriate, but we have no way of knowing this. Furthermore, a recent model suggests that therapy may be necessary at high dosage and for prolonged periods if the animal data are to be reproduced in humans. ${ }^{91}$ The message is that potential cellular and molecular surrogates should be identified and monitored in all patients entering immunotherapy studies. When it is unclear what to monitor we should, perhaps, adopt a "genomics" approach, monitoring the activity of a panel of genes, to look for markers of therapeutic success. On the positive side, a number of exciting therapies are on the horizon. CD28 blockade is already being employed in phase II trials in psoriasis and rheumatoid arthritis. Anti-CD40 mAbs will also be available very soon, as will a new generation of cytokine specific therapies.
Although the clinical success of immunomodulation has not been as profound so far as in experimental models, long term remission has been achieved in some patients following short term therapy. Furthermore, in the future combination approaches may prove more successful than monotherapies, and are already being piloted in rheumatoid arthritis. ${ }^{92}$ Provided clinical studies are also used to address appropriate scientific questions, we should slowly move towards the goal of true immunological tolerance in humans.

ANDREW D DICK

Department of Ophthalmology, University of Aberdeen JOHN D ISAACS

Department of Rheumatology, University of Leeds

Correspondence to: Dr Andrew D Dick, Department of Ophthalmology, University of Aberdeen Medical School, Foresterhill, Aberdeen AB25 2ZD.

1 Suttorp-Schultern MSA, Rothova A. The possible impact of uveitis in blindness: a literature survey. Br f Ophthalmol 1996;80:844-9.

2 Rothova A, Suttorp-Schulten MSA, Treffers WF, et al. Causes and frequency of blindness in patients with intraocular inflammatory disease. $\mathrm{Br}$ f Ophthalmol 1996;80:332-6.

3 Howe LJ, Stanford M, Edelsten C, et al. The efficacy of systemic steroids in sight-threatening retinal vasculitis. Eye 1994;8:443-8.

4 Gordon GM. Prednisolone and prednisone in ocular disease. Am 7 Ophthalmol 1956;41:593-600.

5 Dick AD, Azim M, Forrester JV. Immunosuppressive therapy for chronic uveitis: optimising therapy with steroids and cyclosporin A. Br f Ophthalmol 1997;81:1107-12

6 Ishioka M, Ohno S, Nakamura S, et al. FK 506 treatment of non-infectious uveitis. Am f Ophthalmol 1995;118:723-30.

7 Larkin G, Lightman S L. Mycophenolate mofetil: a useful immunosuppressive in inflammatory eye disease. Ophthalmology 1999;106:370-5.

8 Kilmartin DJ, Forrester JV, Dick AD. Rescue therapy with mycophenolate mofetil in refractory uveitis. Lancet 1998;352:35-6.

9 Forrester JV. Uveitis: pathogenesis. Lancet 1992;388:1498-501.

10 Forrester JV. Duke Elder lecture: new concepts on the role of autoimmunity in the pathogenesis of uveitis. Eye 1992;5:433-47.

11 Cobbold SP, Qin S, Leong LYW, et al. Reprogramming the immune system for peripheral tolerance with CD 4 and CD 8 monoclonal antibodies. Immunol Rev 1992;129:165-201.

12 Forrester JV, Liversidge J, Dua HS, et al. Comparison of clinical and experimental uveitis. Curr Eye Res 1990;9:75-84

13 Caspi RR, Roberge FG, McAllister CG, et al. T cell lines mediating experimental autoimmune uveoretinitis (EAU) in the rat. F Immunol 1986;136: 928-33.

14 Smith JR, Hart PH, Parish CR, et al. Experimental melanin-induced uveitis in the Fischer 344 rat is inhibited by anti-CD4 monoclonal antibody, but not by mannose-6-phosphate. Clin Exp Immunol 1999;115:64-71.

15 Crane IJ, Kuppner MC, McKillop-Smith S, et al. Cytokine regulation of RANTES production by human retinal pigment epithelial cells. Cell Immunol 1998;184:37-44.

16 Forrester JV, Lumsden L, Liversidge L, et al. Immunoregulation of uveoretinal inflammation. Prog Ret Res 1995;14:393-411.

17 Forrester JV, McMenamin PG, Holthouse I, et al. Localisation and characterisation of major histocompatibility complex class II-positive cells in the posterior segment of the eye: implications for induction of autoimmune posterior segment of the eye: implications for induction
uveoretinitis. Invest Ophthalmol Vis Sci 1994;35:64-77.

18 Dick AD, Ford AL, Forrester JV, et al. Flow cytometric identification of a minority population of MHC class II-positive cells in the normal rat retina distinct from $\mathrm{CD} 45^{\text {low }} \mathrm{CD} 1 \mathrm{~b} / \mathrm{c}^{+} \mathrm{CD} 4^{\text {low }}$ parenchymal microglia. $\mathrm{Br} \quad \mathrm{f}$ Ophthalmol 1995;79:834-40.

19 Kuppner M, Liversidge J, McKillop-Smith S, et al. Adhesion molecule expresion in acute and fibrotic sympathetic ophthalmia. Curr Eye Res 1993; 10:923-34.

20 Hossain P, Liversidge J, Cree MJ, et al. In vivo cell tracking by scanning laser ophthalmoscopy: quantification of leukocyte kinetics. Invest Ophthalmol Vis Sci 1998;39:1879-87.

21 De Smet MD, Yamamoto JH, Mochizuki M, et al. Cellular immune responses of patients with uveitis to retinal antigens and their fragments. Am f Ophthalmol 1990;110:135-42.

22 Gupta D, Siingh VK, Rajasingh J, et al. Cellular immune responses of patients with juvenile chronic arthritis to retinal antigens and their patients with juvenile chronic arthritis to retin
synthetic peptides. Immunol Res 1996;15:74-83.

23 Nussenblatt RB, Gery I, Ballentine EJ, et al. Cellular immune responsiveness of uveitis patients to retinal S-Ag. Am f Ophthalmol 1980;89:172-9.

24 Saxena S, Rajasingh J, Biswas S, et al. Cellular immune response to retinal S-antigen and interphotoreceptor retinoid binding protein fragments in Eales' disease. Pathobiology 1999;67:39-44.

25 Yamamoto JH, Minami M, Inaba G, et al. Cellular immune responses of patients with uveitis to retinal antigens and their fragments. Am f Ophthalmol 1993;77:584-9.

26 Gery I, Mochizuki M, Nussenblatt RB. Retinal specific antigens and immunopathogenic processes they provoke. Progr Retinal Res 1986;5:75-109.

27 Feron EJ, Calder VL, Lightman SL. Distribution of IL-2R and CD45Ro expression on CD4+ and CD8+ T lymphocytes in the peripheral blood of patients with posterior uveitis. Curr Eye Res 1992;11(suppl):167-73.

28 Dick AD, Cheng YF, Purdie AT, et al. Immunocytochemical analysis of blood lymphocytes in uveitis. Eye 1992;6:643-7.

29 Sugi-Ikai N, Nakazawa $M$, Nakamura S, et al. Increased frequencies of interleukin-2 and interferon-gamma-producing $\mathrm{T}$ cells in patients with interleukin-2 and interferon-gamma-producing T cells in patients
active Behçet's disease. Invest Ophthalmol Vis Sci 1998;39:996-1004.

30 Murray PI, Young DW. Soluble interleukin-2 receptors in retinal vasculitis. Curr Eye Res 1992;11(suppl): 193-5. 
31 Arocker-Mettinger E, Steurer-Georgiew L, Steure M, et al. Circulating ICAM-1 levels in serum of uveitis patients. Curr Eye Res 1992:11:161-6.

32 Whitcup SM, Vistica BP, Magone MT, et al. Elevated serum levels of soluble ICAM-1 in uveitis patients predict underlying systemic disease. $\mathrm{Br} f$ Ophthalmol 1999;83:252-3.

33 Zaman A, Edelsten C, Stanford M, et al. Soluble intercellular adhesion molecule-1 (sICAM-1) as a marker of disease relapse in idiopathic uveoretinitis. Clin Exp Immunol 1994;95:60-5.

34 Nussenblatt RB, Rodrigues MM, Walker WB, et al. Cyclosporin A: inhibition of experimental autoimmune uveitis in Lewis rat. 7 Clin Invest $1981 ; 67: 1228-332$.

35 Chanaud NP, Vistica BP, Eugui E, et al. Inhibition of experimental autoimmune uveoretinitis by mycophenolate mofetil, an inhibitor of purine metabolism. Exp Eye Res 1995;61:429-34.

36 Dick AD, Kreutzer B, Laliotou B, et al. Effects of mycophenolate mofetil on nasal mucosal tolerance induction. Invest Ophthalmol Vis Sci 1998:39:83540 .

37 Guex-Crosier Y, Raber J, Chan CC, et al. Humanised antibodies against the alpha-chain of the IL-2 receptor and against the beta-chain shared by the IL-2 and IL-15 receptors in a monkey uveitis model of autoimmune diseases. F Immunol 1997;158:452-8.

38 Higuchi $\mathrm{M}$, Diamantstein $\mathrm{T}$, Osawa $\mathrm{H}$, et al. Combined anti-interleukin-2 receptor and low-dose cyclosporine therapy in experimental autoimmune uveoretinitis. 7 Autoimm $1991 ; 4: 113-24$.

39 Tarrant TK, Silver PB, Wahlsten JL, et al. Interleukin 12 protects from a T helper 1-mediated autoimmune disease, experimental autoimmune uveitis, through a mechanism involving interferon-gamma, nitric oxide and apoptosis. F Exp Med 1999;189:219-30

40 Dick AD, McMenamin PG, Korner H, et al. Inhibition of tumour necrosis factor activity minimises target organ damage in experimental autoimmune uveoretinitis despite quantitatively normal activated $\mathrm{T}$ cell traffic to the retina. Eur F Immunol 1996;26:1018-25.

41 Dick AD, Duncan L, Hale G, et al. Neutralizing TNF-alpha activity modulates $T$ cell phenotype and function in experimental autoimmune uveoretinitis. F Autoimmun 1998;11.

42 Atalla L, Linker-Israeli M, Steinman L, et al. Inhibition of autoimmune uveitis by anti-CD4+ antibody. Invest Ophthalmol Vis Sci 1990;31:7-11.

43 Jabs DA, Prendergrast RA. Autoimmune ocular disease in MLR/Mp-lpr/lpr mice is suppressed by anti-CD4 antibody. Invest Ophthalmol Vis Sci 1991;32:2718-22.

44 Whitcup SM, Kozhich AT, Lobanoff M, et al. Blocking both E-selectin and $\mathrm{P}$-selectin inhibits endotoxin-induced leukocyte infiltration into the eye. Clin Immunol Immunopathol 1997;83:45-52.

45 Whitcup SM, Hikita N, Shirao M, et al. Monoclonal antibodies against CD54 (ICAM-1) and CD11a (LFA-1) prevent and inhibit endotoxininduced uveitis. Exp Eye Res 1995;60:587-601.

46 Yokoi H, Kato K, Kezuka T, et al. Prevention of experimental autoimmune uveoretinitis by monoclonal antibody to interleukin-12. Eur $\mathcal{f}$ Immunol 1997;27:641-6.

47 Sartani G, Silver PB, Chan CC, et al. Anti-tumour necrosis factor alpha therapy suppresses the induction of experimental autoimmune uveoretinitis in mice by inhibiting antigen priming. Invest Ophthalmol Vis Sci 1996;37: 2211-18

48 Cope AP. Regulation of autoimmunity by proinflammatory cytokines. Curr Opin Immunol 1998;10:669-76.

49 Pleyer U, Milani JK, Dukes A, et al. Effect of topically applied anti-CD4 monoclonal antibodies on orthoptic corneal allografts in a rat model. Invest Ophthalmol Vis Sci 1995;36:52-61.

50 Ayliffe W, Alam Y, Bell EB, et al. Prolongation of rat corneal graft survival by treatment with anti-CD4 monoclonal antibody. Br 7 Ophthalmol 1992;76: 602-6.

51 Wetzig R, Hooks JJ, Percopo CM, et al. Anti-Ia antibody diminishes ocular inflammation in experimental autoimmune uveoretinitis. Curr Eye Res 1988;7:809-18.

52 Calder VL, Zhao ZS, Wang Y, et al. Effects of CD8 depletion on retinal soluble antigen induced experimental autoimmune uveoretinitis. Immunology 1993;79:255-62.

53 He Y, Mellon J, Apte R, et al. Effect of LFA-1 and ICAM-1 antibody treatment on murine corneal allograft survival. Invest Ophthalmol Vis Sci 1994; 35:3218-25.

54 Uchio E, Kijima M, Tanaka S, et al. Suppression of experimental uveitis with monoclonal antib

55 Yamagami S, Obata H, Tsuru T, et al. Suppression of corneal allograft rejection after penetrating keratoplasty by antibodies to ICAM-1 and LFA-1 in mice. Transplant Proc 1995;27:1899-900.

mice. Transplant Proc 1995;27:1899-900.
56 Hori J, Isobe M, Yamagami S, et al. Acceptance of second corneal allograft by combination of anti-VLA-4 and anti-LFA-1 monoclonal antibodies in mice. Transplant Proc 1998;30:200-1.

57 Hori J, Yamagami S, Obata $\mathrm{H}$, et al. Effect of monoclonal antobody to VLA-4 on corneal allograft survival in mice. Transplant Proc 1996;28:1990-

58 Smith JR, Hart PH, Coster DJ, et al. Mice deficient in tumour necrosis factor receptors p 55 and $\mathrm{p} 75$, interleukin-4, or inducible nitric oxide synthase are susceptible to endotoxin-induced uveitis. Invest Ophthalmol Vis $\mathrm{Sci}$ 1998;39:658-61.

59 Kasner L, Chan CC, Whitcup SM, et al. The paradoxical effect of tumour necrosis factor alpha (TNF-alpha) in endotoxin-induced uveitis. Invest Ophthalmol Vis Sci 1993;34:2911-17.

60 De Vos AF, Van Haren MA, Verhagen C, et al. Systemic anti-tumour necrosis factor antibody treatment exacerbates endotoxin-induced uveitis in the rat. Exp Eye Res 1995;61:667-75.
61 Ramanathan S, de Kozak Y, Saoudi A, et al. Recombinant Il-4 aggravates experimental autoimmune uveoretinitis in rats. 7 Immunol 1996;157:220915

62 Cobbold SP, Marshall SE, Davies JD, et al. Mechanisms of peripheral tolerance and suppression induced by monoclonal antibodies to CD4 and CD8. Immunol Rev 1996;149:5-33.

63 Shizuru JA, Taylor-Edwards C, Banks BA, et al. Immunotherapy to the nonobese diabetic mouse: treatment with an antibody to helper T cells. Science 1988;240:659-62.

64 Steinamn L, Rosenbaum JT, Sriram S, et al. In vivo protective effects of antibodies to immune response gene products: prevention of experimental allergic encephalitis. Proc Natl Acad Sci USA 1981;78:7111-14.

65 Wofsy D, Seaman WE. Successful treatment of autoimmunity in NZB.NZW mice with monoclonal antibody to L3T4. F Exp Med 1985;161:378.

66 Ranges GE, Sriram S, Cooper SM. Prevention of type II collagen-induced athritis by in vivo treatment with anti-L3 T4. F Exp Med 1985;162:1105-10.

67 Wraith DC, McDevitt HO, Steinamn L, et al. T cell recognition as the target for immune intervention in autoimmune disease. Cell 1989;57:709-15.

68 Lenschow DJ, Ho SC, Sattar H, et al. Differential effects of anti-B7-1 and anti-B7-2 monoclonal antibody treatment on the develoment of diabetes in the nonobese diabetic mouse. F Exp Med 1995;181:1145-55.

69 Khoury SJ, Akalin E, Chandraker A, et al. CD28-B7 costimulatory blockade by CTLA4Ig prevents actively induced experimental autoimmune encephalomyelitis and inhibitis Th1 but spares Th2 cytokines in the central nervous system. F Immunol 1995;155:4521-4.

70 Isaacs JD, Burrows N, Wing $\mathrm{M}$, et al. Humanised anti-CD4 monoclonal antibody therapy of autoimmune and inflammatory disease. Clin Exp Immunol 1997;110:158-66.

71 Isaacs JD, Waldmann H. Regaining self-control-regulation and immunotherapy. Br $\mathcal{F}$ Rheumatol 1998;37:926-9.

72 Isaacs JD, Dick AD, Haynes RJ, et al. Monoclonal antibody therapy of chronic intraocular inflammation using Campath-1H. $\mathrm{Br} \mathcal{F}$ Ophthalmol 1995;79:1054-5.

73 Newman DK, Isaacs JD, Watson PG, et al. Prevention of immune-mediated corneal graft destruction with the anti-lymphocyte monoclonal antibody, Campath-1H. Eye 1995;9:564-9.

74 Moreau T, Thorpe J, Miller D, et al. Preliminary evidence from magnetic resonance imaging for reduction in disease activity after lymphocyte depletion in multiple sclerosis. Lancet 1994;344:298-301.

75 Lockwood CM, Thiru S, Stewart S, et al. Treatment of refractory Wegener's granulomatosis with humanised monoclonal antibodies. Qf Med 1996;89: 903-12.

76 Moreland LW, Baumgartner SW, Schiff MH, et al. Treatment of rheumatoid arthritis with a recombinant human tumour necrosis factor receptor (p75)-Fc fusion protein. N Engl f Med 1997;337:141-7.

77 Elliott MJ, Maini RN, Feldmann M, et al. Randomised double blind comparisn of a chimeric monoclonal antibody to tumour necrosis factor alpha (cA2) versus placebo in rheumatoid arthritis. Lancet 1994;344:110510 .

78 Breshnihan B, Alvaro-Gracia JM, Cobby M, et al. Treatment of rheumatoid arthritis with recombinant human interleukin-1 receptor antagonist. Arthritis Rheum 1998;41:2196-204.

79 Isaacs JD. Side-effects from biologics in the therapy of rheumatic diseases. Inflammopharmacology 1995;3:379-88.

80 Neuberger MS, Williams GT, Fox RO. Recombinant antibodies possessing novel effector functions. Nature 1984;312:604-6.

81 Reichmann L, Clark M, Waldmann H, et al. Reshaping human antibodies for therapy. Nature 1988;332:323-7.

82 Winter G, Mistein C. Man-made antibodies. Nature 1991;349:293-9.

83 Isaacs JD, Greenwood J, Waldmann H. Therapy with monoclonal antibodies II: The contribution of Fc161:3262-9 receptor binding and the influence of $\mathrm{CH} 1$ and $\mathrm{CH} 3$ domains on in vivo effector function. $\mathcal{F}$ Immunol 1998;161:3862-9.

84 Isaacs JD, Manna VK, Rapson N, et al. Campath-1H in rheumatoid arthritis - an iv dose-ranging study. Br f Rheumatol 1996;35:231-40.

85 Maini RN, Breedveld FC, Kalden JR, et al. Therapeutic efficacy of multiple intravenous infusions of anti-tumor necrosis factor $\alpha$ monoclonal antibody combined with low-dose weekly methotrexate in rheumatoid arthritis. Arthritis Rheum 1998;41:1552-63.

86 Sainz de la Maza M, Foster CS, Jabbur NS. Scleritis associated with systemic vasculitic diseases. Ophthalmology 1995;102:687-92.

87 Isaacs J, Dick AD. Short term immunosuppressive therapy and long term immunoregulation: promises and problems. Br f Ophthalmol 1996;80: $1035-7$

88 Thurau SR, Wildner G, Reiter C, et al. Treatment of endogenous uveitis with anti-CD4 monoclonal antibody: first report. Ger F Ophthalmol 1994;3: 409-13.

89 Whitcup SM. New therapeutic approaches for ocular inflammatory disease. Ocul Immunol Inflamm 1998;6(suppl): S1.

90 Vincenti F, Kirkman R, Light S, et al. The Daclizumab triple therapy study group. Interleukin-2-receptor blockage with daclizumab to prevent acute reaction in renal transplantation. $N$ Engl f Med 1998;338:161-5.

91 Waldmann H, Cobbold SP. How may immunosuppression lead to tolerance? The war analogy. In: Plotkin S, Fanatini B, eds. Immune tolerance. Paris: Elsevier, 1997

92 Morgan A, Hale G, Waldmann H, et al. Prolonged combination therapy of rheumatoid arthritis using CD4 and TNF-alpha blockade: a pilot study. Arthritis Rheum 1998;41:s55. 